\title{
Detection of Helicobacter pylori in Drinking Water by Loop-Mediated Isothermal Amplification
}

\author{
Ramin Abiri, ${ }^{1}$ Shahram Bagherabadi, ${ }^{1,2}$ Mahsa Kashef, ${ }^{1,2}$ Banafsheh Hasanvand, ${ }^{1,2}$ Hamid Pajavand, ${ }^{1,2}$ \\ Abolfazl Gholipour, ${ }^{3}$ Mohsen Azizi, ${ }^{1,2}$ and Amirhooshang Alvandi ${ }^{1, *}$ \\ ${ }^{1}$ Microbiology Department, Faculty of Medicine, Kermanshah University of Medical Sciences, Kermanshah, IR Iran \\ ${ }^{2}$ Students Research Committee, Faculty of medicine, Kermanshah University of Medical Sciences, Kermanshah, IR Iran \\ ${ }^{3}$ Department of Microbiology and Immunology, Cellular and Molecular Research Center, Shahrekord University of Medical Sciences, Shahrekord, IR Iran \\ "Corresponding author: Amirhooshang Alvandi, Department of Microbiology, Faculty of Medicine, Kermanshah University of Medical Sciences, Shirudi Blvd., Parastar Blvd, \\ Postal Code: 6714869914, Kermanshah, IR Iran. Tel: +98-918839-8490, Fax: +98-833427-4623, E-mail: ah_alvandi@kums.ac.ir
}

Received 2016 August 29; Revised 2016 December 14; Accepted 2017 January 01.

\begin{abstract}
Background: There should be a public environmental reservoir for Helicobacter pylori in the developing countries, such as Iran, due to their high infection rate of over 70\%. Epidemiological findings revealed that water could be a possible source of $H$. pylori transmission. However, high prevalence of H. pylori in drinking water in Kermanshah, West of Iran, was detected in the authors' previously published study. The current study aims at designing a more accurate and rapid procedure to investigate the prevalence of Helicobacter species and cagA gene in drinking water samples in Kermanshah, from October to December 2012.

Methods: In the current study, 60 tap water samples were obtained and specific polymerase chain reaction (PCR) targeted cagA and 16s rRNA was performed. A loop-mediated isothermal amplification (LAMP) targeted ureC gene was developed to accurately detect H. pylori in water samples.

Results: The prevalence of ureC by PCR, ureC by LAMP and 16s rRNA by PCR were $26.67 \%, 38 \%$, and 61.67\%, respectively. Among 24 samples (40\%), 1 of the 2 tests was positive. The prevalence of $c a g A$ gene among ureC positive, $16 \mathrm{~s} r$ RNA positive and all samples were $18.75 \%, 13.51 \%$, and $10 \%$, respectively.

Conclusions: Helicobacter pylori contamination in drinking water was considerably higher using LAMP compared with PCR. It is noteworthy that some $H$. pylori positive samples were also positive for Caga.
\end{abstract}

Keywords: Drinking Water, LAMP, PCR, Helicobacter pylori, ureC, cagA

\section{Introduction}

Helicobacter pylori are spiral-shaped, microaerophilic, Gram-negative bacteria, and the main cause of gastroduodenal diseases (1). The prevalence of $H$. pylori infection in some developing countries is more than $80 \%$ and below $20 \%$ in some developed countries (2). Man is a major reservoir of the bacteria and colonization remains for a lifetime unless treated. The mode of transmission of $H$. pylori is from person to person with 2 route of transmission being proposed: fecal-oral, oral-oral, and/or stomach-oral routes. Studies suggest that the infection transmits through saliva and dental plaque, and normal and diarrheal stools (3). However, several studies show that low standard of living and crowded households are the major risk factors for contracting $H$. pylori infection $(4,5)$. Researches suggest environmental reservoirs such as food, water and domestic animal for $H$. pylori. To support this hypothesis, numerous studies are carried out to report the presence of $H$.pylori in such environments (6-10).

The presence of Helicobacter spp. is investigated in nat- ural environmental waters, including ground water, fresh water streams, and off-shore marine waters using molecular technique, but it is rarely isolated from these kinds of samples (11-16). Since $H$. pylori have the propensity for exhibiting 2 forms: spiral and coccoid. The spiral-shaped form is metabolically active while the coccoid shape is formed under stressful conditions $(17,18)$. Some authors consider the coccoid form as dormant and viable (17, 1921). Morphological change from spiral to coccoid makes the organism non-culturable (22). The coccoid form can change into the spiral form under certain conditions and this supposition increases the risk of H.pylori transmission through water. Studies show that the coccoid form of $H$. pylori, with a smaller amount of DNA and mRNA relative to the spiral form, has oxidative metabolism and respiration $(18,23)$. Therefore, water can play a major role in $H$. pylori transmission and the bacteria can survive as long as 20 days in distilled water, while their pathogenic ability remains (24).

The survival of $H$. pylori in water may also depend on specific factors such as the presence of free living amoeba 
and zooplanktons (25). Some studies show that $H$. pylori can be incorporated into the biofilm, which is an important factor for successful survival in the aquatic environment $(26,27)$. For successful long-term colonization in the human stomach, H. pylori harbors a set of bacterial virulence determinants; Cytotoxin-associated antigen ( $\operatorname{cag} A$ ) is 1 of widely disseminated genes with $90 \%$ prevalence among Asian population and is believed to increase the risk of gastric cancer (28). Therefore, the presence of this gene in water could be a risk factor for cancer development.

In the current study, the following hypothesis was devised based on the author's previous studies: the presence of H. pylori was detected using PCR method targeting ureC gene. Therefore, the current study was used to determine if the analytical method commonly used for other bacteria can be used to evaluate and estimate the presence of H. pylori in water. Also, in the current study, cagA and 16s rRNA genes were targeted by PCR, and ureC for the Loopmediated isothermal amplification (LAMP) method. For this purpose, a highly specific PCR method was developed and then the obtained results were compared with those of LAMP to evaluate the sensitivity and specificity of the LAMP method to detect $H$. pylori DNA in water or human samples; where a very high rate of $H$. pylori infection is recently shown $(29,30)$. In addition, samples were collected and analyzed with rigorous controls for false positive or negative results.

\section{Methods}

\subsection{Sample Collection and Preparation}

As mentioned in the authors' previous study, samples were collected from urban tap and well water sources in Kermanshah from June to November 2012 (12). Kermanshah is a mountainous city with mild climate, and is the capital city of the province located in the Western part of Iran (31). The drinking water supplies Kermanshah come from 133 wells and Gavshan dam, which is connected to 21 reservoir tanks and distributed around the city (32).

\subsection{DNA Preparation}

The drinking water samples were obtained from taps of all water supplies. For each sample, 1 liter of water was obtained and filtered through $0.45 \mu \mathrm{m}$ nitrocellulose filters (12). Finally, the DNA of the filtered bacteria was extracted using QIAAmp Mini DNA kit (Qiagen, Germany), according to the manufacturer's instructions. In the authors' previous study, the presence of H. pylori was analyzed using only PCR. Here, to evaluate the presence of 16s rRNA, cagA, and $u r e C$ genes, $\mathrm{PCR}$ was amplified using specific primers;
LAMP targeted species specific ureC gene on the DNAs extracted from the samples.

\subsection{Primer Design}

The primers used in PCR in the current study were retrieved from previously published articles. Oligonucleotide primers targeting ureC (GenBank accession no. AE000511) for LAMP were designed using LAMP primer design software (http://primerexplorer.jp/e/index.html). The 2 outer primers were designated as forward outer primer (UreCF3) and backward outer primer (UreCB3). The inner primers were designated as Forward Inner Primer (UreC FIP) and Backward Inner Primer (UreC BIP). The loop primers were designated as forward and backward Loop Primers, (UreC LF) and (UreC LB), respectively. Complete sets of primers and their sequences are shown in Table 1.

\subsection{PCR Assay}

Optimal PCR reaction was carried out according to the procedure laid down in a previous article of the authors. In summary, the process was carried out using a final volume of $15 \mu \mathrm{L}$ containing $20 \mathrm{mM}$ Tris- $\mathrm{HCl}$ (Cinacolon, Iran) , 50 $\mathrm{mM} \mathrm{KCl}, 200 \mu \mathrm{M}$ dNTP mix (Cinacolon, Iran), $1.5 \mathrm{mM} \mathrm{MgCl}_{2}$, $0.5 \mu \mathrm{M}$ of each forward and reverse primers (Takapouzist, Iran), 1 unit Taq DNA polymerase (Cinacolon, Iran), and 5 $\mu \mathrm{L}$ of template DNA. Initial denaturation of the target DNA was at $95^{\circ} \mathrm{C}$ for 5 minutes as well as 214,422 , and $349 \mathrm{bp} \mathrm{tar}$ get sequences were amplified in the reaction mix through 35 cycles as follows: $92^{\circ} \mathrm{C}$ for 30 seconds, $55^{\circ} \mathrm{C}$ for 30 seconds (ureC), $58^{\circ} \mathrm{C}$ for 30 seconds (cagA), $45^{\circ} \mathrm{C}$ for 30 seconds (16s rRNA gene) and $72^{\circ} \mathrm{C}$ for 30 seconds, followed by $72^{\circ} \mathrm{C}$ for 5 minutes. Electrophoresis through 1\% agarose gel and staining with ethidium bromide were done on PCR product.

\subsection{Loop-Mediated Isothermal Amplification Assay}

Loop-mediated isothermal amplification was carried out in a total volume of $30 \mu \mathrm{L}$ reaction volume. The LAMP system contained $1.6 \mu \mathrm{M}$ of each FIP and BIP, $0.2 \mu \mathrm{M}$ of each F3 and B3, $0.8 \mu \mathrm{M}$ of each LF and BF, 8 U Bst polymerase, $3 \mu \mathrm{L}$ of genomic DNA, 2 mM each dNTP (TransGen Biotech), 0.8 $\mathrm{M}$ betaine (Sigma, St. Louis, MO, USA), $20 \mathrm{mM}$ Tris-HCl, 10 $\mathrm{mM} \mathrm{KCL}, 10 \mathrm{mM}\left(\mathrm{NH}_{4}\right) 2 \mathrm{SO} 4,12 \mathrm{mM} \mathrm{MgSO}_{4}$ that was mixed and mixture transferred to microtubes. The reaction mixture was heated at $95^{\circ} \mathrm{C}$ for 3 minutes in thermocycler and then chilled on ice, $8 \mathrm{U}$ Bst polymerase (New England Biolabs, USA) were added followed by incubation at $65^{\circ} \mathrm{C}$ for 60 minutes, and was heated at $96^{\circ} \mathrm{C}$ for 2 minutes and cooled at $4^{\circ} \mathrm{C}$ for 5 minutes to terminate the reaction (35). 
Table 1. Primers Used in the Current Study

\begin{tabular}{|c|c|c|c|c|}
\hline Primer & Sequence (5' - 3') & Position & Product Size & Reference \\
\hline HP-UreCBIP & CTCGCCTCCAAAATTGGCTTGCGATTGGGGATAAGTTTG & & & \multirow{6}{*}{ The current study } \\
\hline HP-UreCFIP & GCATATCATTTTTAGCGATTACGCTCACTAACGCGCTCACTTG & & & \\
\hline HP-UreCB3 & TCCCAAGATTTGGAATTGAAG & & & \\
\hline HP-UreCF3 & GCTTACCTGCTTGCTTTC & & & \\
\hline HP-UreCLB & TCAATTGCATGCATTCGCTCA & & & \\
\hline HP-UreCLF & CAGGCGATGGTTTGGTGTG & & & \\
\hline \multirow{2}{*}{ ureC } & ureCF: CAT CGC CAT CAA AAG CAA AG & $605-625$ & \multirow{2}{*}{214} & \multirow{2}{*}{ (12) } \\
\hline & ureCR: AGT TTA AGG ATC GTG TTA G & $798-819$ & & \\
\hline \multirow{2}{*}{ 16s rRNA } & Rg; GCTATG ACG GGT ATC C & $276-291$ & \multirow{2}{*}{400} & \multirow{2}{*}{ (33) } \\
\hline & Fg: GAT TTTACC CCT ACA CCA & $681-698$ & & \\
\hline \multirow{2}{*}{$\operatorname{cag} A$} & F1:GATAACAGGCAAGCTTTTGAGG & & \multirow{2}{*}{349} & \multirow{2}{*}{ (34) } \\
\hline & B1:CTGCAAAAGATTGTTTGGCAGA & & & \\
\hline
\end{tabular}

\subsection{Analysis of LAMP Products}

The LAMP products were centrifuged for 3 minutes at $3000 \mathrm{rpm}$, positive samples can be detected through observable magnesium sulfide $\left(\mathrm{MgSO}_{4}\right)$ with sediment at the bottom of microtubes. Negative LAMP products with no observable sediment were subjected to electrophoresis through $1.5 \%$ agarose gels then visualized under UV light after staining with ethidium bromide (Cinacolon, Iran) to prove negativity.

\subsection{Determination of Primers Specificity in LAMP Reaction}

To determine the specificity of LAMP primers, the primers were set up in a LAMP reaction with the DNA of other bacterial species such as Citrobacter, Campylobacter, Klebsiella, Yersinia, Shigella, and Pseudomonas, in addition to Enterococcus faecalis and Salmonella typhi.

\subsection{Determination of Analytical Sensitivity}

Furthermore, analytical sensitivity was carried out to detect the sensitivity of LAMP. Here, a suspension of 3 day old culture of $H$. pylori was prepared in a PBS buffer and the number of $H$. pylori was counted using Petroff-Hasser counting chamber. The average number of counted bacteria was used as the basis for multiple suspensions, which was approximately 1 to 100,000 bacteria per liter of water. The sensitivity of LAMP was evaluated with a detection limit and after DNA extraction of $H$. pylori, the concentration of DNA was measured 3 times using the Nonodrop spectrophotometer device and the average result was considered as a base to prepare serial dilution with concentrations of $10 \mathrm{ng} /$ reaction to $0.01 \mathrm{fg} /$ reaction.

\subsection{Detection Limit}

The sensitivity, specificity, and negative and positive predicting values of LAMP method, in line with PCR, were measured.

\subsection{Statistical Analysis}

Data were analyzed by SPSS software version 16 . To calculate the degree of agreement between the 2 methods, Kappa coefficient was used. The gold standard for H. pylori detection was PCR method. Loop-mediated isothermal amplification sensitivity and specificity, negative and positive predicting values and its agreement with PCR was calculated using Table 2 .

Table 2. Specificity and Sensitivity Calculation

\begin{tabular}{l|c|c|c}
\hline \multirow{2}{*}{} & & \multicolumn{2}{c}{ Gold Standard (PCR) } \\
\cline { 3 - 4 } & PAMP & Positive & Negative \\
\hline \multirow{3}{*}{ Positive } & a (True positives) & $\mathrm{b}$ (False - positives) \\
\cline { 2 - 4 } & Negative & $\begin{array}{c}\mathrm{c} \text { (False - } \\
\text { negatives) }\end{array}$ & $\mathrm{d}$ (True negatives) \\
\hline
\end{tabular}

\section{Results}

\subsection{PCR and LAMP Results}

In a total of 60 drinking water samples, 16 (26.67\%) were positive for ureC by PCR, 20 (33.33\%) were positive for ureC by LAMP, and 37 (61.67\%) were positive for $16 s$ rRNA by PCR. Overall, detection rate based on ureC gene by PCR and LAMP was $26 \%$. 
The prevalence of cagA gene among ureC positive samples was 3/16 (18.75\%). But among 37 samples positive for 16s $r R N A$, 5 samples (13.51\%) were also positive for cagA gene. The overall detection rate of $\operatorname{cag} A$ was $10 \%$ (6/60). Figure $1 \mathrm{~A}$ and $1 \mathrm{~B}$ show the PCR electrophoresis products of $16 \mathrm{~s} r R N A$ and cagA genes.

\subsection{Loop-Mediated Isothermal Amplification Specificity}

The evaluation of primers specificity in LAMP reaction for ure $C$ gene of $H$. pylori was done to decline any complementary relevancy between these primers and other bacterial genes in water. The results showed that the primers designed for ureC to be used in LAMP reaction were $100 \%$ specific for $H$. pylori.

\subsection{Loop-Mediated Isothermal Amplification Sensitivity}

The analytical sensitivity of the LAMP method was 50 bacteria per liter with observable sediment, but after electrophoresis, the sensitivity improved to 1 bacterium per liter. The ability of the LAMP reaction to detect $H$. pylori, using pure DNA of the bacterium, was $10 \mathrm{fg} /$ reaction (Figure 2). In the current study, the sensitivity, specificity, negative and positive predicting values of the LAMP to detect $H$. pylori in water samples were $100.00 \%, 90.91 \%, 100.00 \%$, and $80.00 \%$, respectively and the efficacy of the LAMP was $100 \%$ in comparison with that of PCR, which is the gold standard. Kappa coefficient and agreement between LAMP and PCR were 0.84 and 93\%, respectively. The agreement between the 2 tests was excellent and can be used parallel to PCR.

\section{Discussion}

Adequate knowledge regarding the reservoirs and modes of transmitting $H$. pylori could help to explain the high prevalence of the bacteria. The incidence of $H$. pylori is high in the developing countries (90\%), whereas in the industrialized countries, the figure is lower (50\%) and tends to decrease. Childhood is the critical period for infection, and transmission usually occurs from person to person (2, $10,36,37)$. In an endemic area, a common source of infection is suspected (38).

Data of the present study showed that $H$. pylori can be detected in Kermanshah municipal tap water and the consumption of such water could be associated with gastric colonization of the organism. These findings were in line with those of the previous studies of the authors, but further investigation is required to determine whether the organism is viable or not (39). These findings also confirmed the previous observations in Isfahan, Iran (13), Colombia (40), Peru (41), Mexico (42), England (43), Sweden (38, 39, $41,42,44)$, Japan (45), and the United States (46). The high prevalence of $H$. pylori detected in drinking water samples strengthens the evidence of $H$.pylori transmission through drinking water. Considering that the $\operatorname{cag} A$ is associated with increased virulence and risk of peptic ulcer and cancer, the present study was the first to report on the presence of $\operatorname{cagA}$ in drinking water samples. A prevalence of $13.51 \%$ of this gene in drinking water is an alarming situation. In a similar study carried out in Pakistan, the prevalence of $16 s$ rRNA and $\operatorname{cagA}$ were $40 \%$ and 0 , respectively (47).

The result obtained for $16 s$ rRNA was considerably high, $61.67 \%$ and $25 \%$ (15/60) of $16 s$ rRNA positive samples were negative for the LAMP of ureC gene. This indicates the likely presence of other Helicobacter spp. other than H. pylori in the water samples. Poor sanitation of water and allowing domestic animals, which could be a carrier of non-pylori Helicobacter species to roam near water supplies, lead to water contamination (48-52). Another probability is the presence of $H$. pylori that has lost its pathogenicity genes (53).

The current study was also the first to report on the possible existence of Helicobacter ssp. in water samples. Nonpylori Helicobacter species are associated with some human diseases and could exacerbate some situations such as inflammatory bowel disease (IBD), and hepatocellular carcinoma (HCC) (54-56). Among the ureC positive samples, $18.75 \%$ were positive for the cagA gene and the overall detection of cagA gene was $13.51 \%$. No study is carried out to detect cagA gene in water, but in a previous study on gastric biopsies, in terms of prevalence, cagA was $84.4 \%$ (30).

The cagA is a $40 \mathrm{kbp}$ gene located in the cag pathogenicity island (PaI) of the H. pylori chromosome (57). It is shown that the presence of $\operatorname{cag} A$ gene is associated with peptic ulcer disease (58), atrophic gastritis (59), and gastric adenocarcinoma (60). The cagA positive strains are more virulent than other strains (61). The presence of $\operatorname{cagA}$ gene in water sample could be a potential risk for cancer development in Kermanshah, Iran. All the mentioned previous studies were based on the PCR of ureC gene or 16s rRNA gene, but in the current study 2 methods of detection were considered; PCR and LAMP. In addition, various genes were employed as a target of amplification, which caused an increase in detection accuracy.

It is noteworthy that it was the first study to report on the use of LAMP reaction to detect $H$. pylori in water samples.

Loop-mediated isothermal amplification is easy to perform if the appropriate primers are prepared, which requires only 6 pairs of primers, DNA polymerase, a bainmarie bath, and a thermocycler for reaction. Loopmediated isothermal amplification is 10-100-fold more analytically sensitive than PCR. Compared to the other ampli- 
A

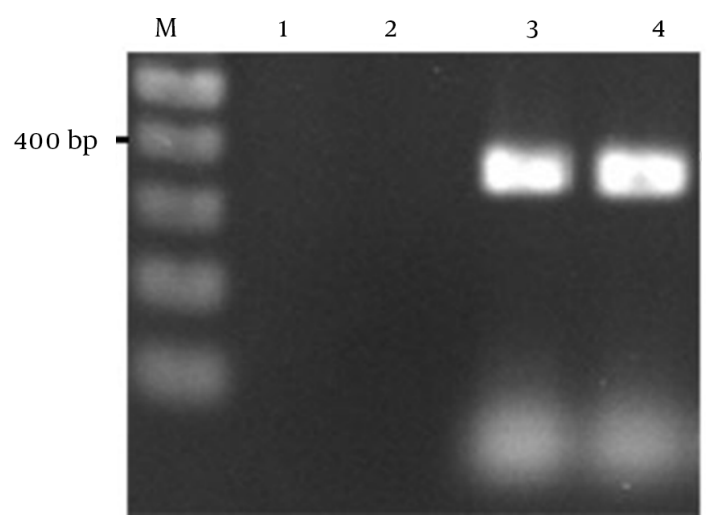

B

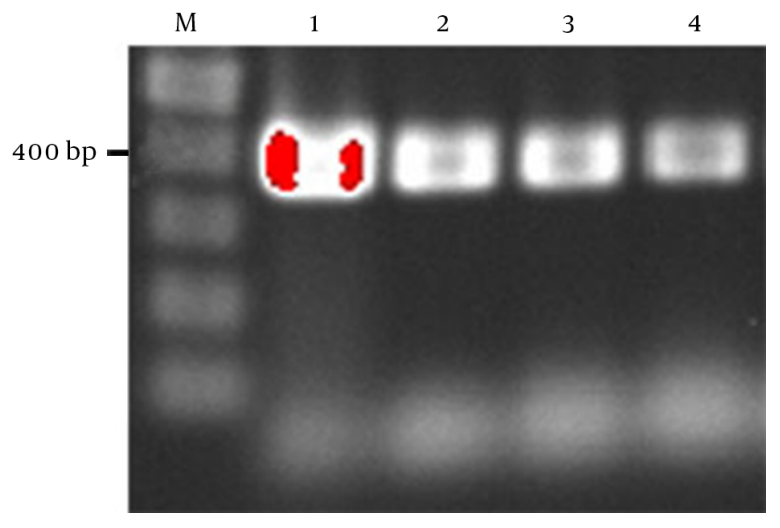

A, Agarose gel electrophoresis of PCR products amplified from drinking water. Lane M, 100 bp DNA ladder; lane 1, negative control; lane 2, drinking water sample negative for H. pylori; lane 3 drinking water sample positive for $H$. pylori; lane 4, positive control; B, agarose gel electrophoresis of PCR products amplified from drinking water targeted cagA; Lane M, 100 bp DNA ladder; lane 1, positive control; lane 2, drinking water sample positive for H. pylori; lane 3 drinking water sample negative for $H$. pylori; lane 4, negative control.

Figure 2. The Electrophoresis of LAMP Product from Different Suspensions of H. pylori

$100 \mathrm{bp}$

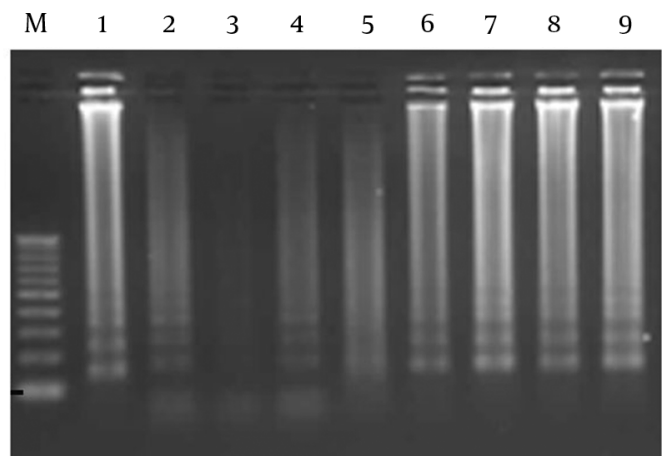

From left to right: lane M. 100 bp DNA Vivantis ladder; lane 1, positive control (151 bp); lane 2, Fifty bacteria per liter; lane 3, negative control; lane 4, one bacterium per liter; lane 5, ten bacteria per liter, lane 6, one hundred bacteria per liter; lane 7, one thousand bacteria per liter; lane 8 , ten thousands bacteria per liter; lane 9, onehundred thousand bacteria per liter.

fication methods, the DNA amplification reaction in LAMP method is carried out under isothermal condition and the efficiency of the amplification is higher and, the detection limit is lower $(62,63)$. The analytical specificity of the LAMP is attributed to 6 sets of primers that recognize 8 distinct regions on the target DNA. The amplified products can be also confirmed using sequencing or digestion with restriction enzyme (64-66). Since the LAMP method is much more analytically sensitive than PCR, therefore, more positive results are obtained in the reactions.
Considering the fact that $\operatorname{cag} A$ is associated with increased virulence, risk of peptic ulcer and cancer, the high prevalence of $H$. pylori and the presence of cagA gene in drinking water is fast becoming an alarming situation. In the current study, 25\% of samples were positive for nonpylori Helicobacter species. However, non-pylori Helicobacter species are linked with chronic infection of the intestinal and hepatobiliary tract. They also disturb immune responses of the intestinal epithelial cells by modulating its inflammatory response, which increases the risk of bacterial infection in the intestine. The contamination of water by these bacteria could be a potential risk to develop some gastrointestinal diseases.

\section{Acknowledgments}

The study was financially supported by Kermanshah University of Medical Sciences. The current study was conducted in microbiology department of Kermanshah University of Medical Sciences.

\section{Footnotes}

Authors' Contribution: The work presented here was carried out in collaboration between all authors who contributed, observed, and approved the manuscript.

Financial Disclosure: The authors declared no conflict of interest under the current study. 


\section{References}

1. Blaser MJ, Atherton JC. Helicobacter pylori persistence: biology and disease. J Clin Invest. 2004;113(3):321-33. doi: 10.1172/JCI20925. [PubMed: 14755326].

2. Bardhan PK. Epidemiological features of Helicobacter pylori infection in developing countries. Clin Infect Dis. 1997;25(5):973-8. [PubMed: 9402340].

3. Akcan Y, Ersan S, Alper M, Bicik Z, Aytug N. The transmission of Helicobacter pylori via exposure to common sources outweighs the person-to-person contact among spouses in developing countries. Am J Gastroenterol. 2000;95(1):317-9. doi: 10.1111/j.15720241.2000.01722.x. [PubMed: 10638617]

4. Brown LM, Thomas TL, Ma JL, Chang YS, You WC, Liu WD, et al. Helicobacter pylori infection in rural China: demographic, lifestyle and environmental factors. Int J Epidemiol. 2002;31(3):638-45. [PubMed: 12055167].

5. Graham DY, Adam E, Reddy GT, Agarwal JP, Agarwal R, Evans DJ, et al. Seroepidemiology of Helicobacter pylori infection in India. Comparison of developing and developed countries. Dig Dis Sci. 1991;36(8):1084-8. [PubMed:1864201].

6. Karita M, Teramukai S, Matsumoto S. Risk of Helicobacter pylori transmission from drinking well water is higher than that from infected intrafamilial members in Japan. Dig Dis Sci. 2003;48(6):1062-7. [PubMed: 12822863].

7. Klein PD, Graham DY, Gaillour A, Opekun AR, Smith EO. Water source as risk factor for Helicobacter pylori infection in Peruvian children. Gastrointestinal Physiology Working Group. Lancet. 1991;337(8756):1503-6. [PubMed: 1675369].

8. Perez-Perez GI, Rothenbacher D, Brenner H. Epidemiology of Helicobacter pylori infection. Helicobacter. 2004;9 Suppl 1:1-6. doi: 10.1111/j.1083-4389.2004.00248.x. [PubMed: 15347299].

9. Vale FF, Vitor JM. Transmission pathway of Helicobacter pylori: does food play a role in rural and urban areas?. Int I Food Microbiol. 2010;138(1-2):1-12. doi: 10.1016/j.ijfoodmicro.2010.01.016. [PubMed: 20122750].

10. van Duynhoven YT, de Jonge R. Transmission of Helicobacter pylori: a role for food?. Bull World Health Organ. 2001;79(5):455-60. [PubMed: 11417041].

11. Adams BL, Bates TC, Oliver JD. Survival of Helicobacter pylori in a natural freshwater environment. Appl Environ Microbiol. 2003;69(12):74626. [PubMed:14660399].

12. Amirhooshang A, Ramin A, Ehsan A, Mansour R, Shahram B. High frequency of Helicobacter pylori DNA in drinking water in Kermanshah, Iran, during June-November 2012.J Water Health. 2014;12(3):504-12. doi: 10.2166/wh.2013.150. [PubMed: 25252354].

13. Bahrami AR, Rahimi E, Ghasemian Safaei H. Detection of Helicobacter pylori in city water, dental units' water, and bottled mineral water in Isfahan, Iran. ScientificWorldJournal. 2013;2013:280510. doi: 10.1155/2013/280510. [PubMed: 23606812].

14. Baker $\mathrm{KH}$, Hegarty JP. Presence of Helicobacter pylori in drinking water is associated with clinical infection. Scand J Infect Dis. 2001;33(10):744-6. [PubMed: 11728039].

15. Benson JA, Fode-Vaughan KA, Collins ML. Detection of Helicobacter pylori in water by direct PCR. Lett Appl Microbiol. 2004;39(3):221-5. doi: 10.1111/j.1472-765X.2004.01555.x. [PubMed:15287865]

16. Luzza F, Imeneo M, Maletta M, Paluccio G, Giancotti A, Perticone F, et al. Seroepidemiology of Helicobacter pylori infection and hepatitis A in a rural area: evidence against a common mode of transmission. Gut. 1997;41(2):164-8. [PubMed: 9301493].

17. Nilius M, Strohle A, Bode G, Malfertheiner P. Coccoid like forms (CLF) of Helicobacter pylori. Enzyme activity and antigenicity. Zentralbl Bakteriol. 1993;280(1-2):259-72. [PubMed: 8280950].

18. She FF, Lin JY, Liu JY, Huang C, Su DH. Virulence of water-induced coccoid Helicobacter pylori and its experimental infection in mice. World
J Gastroenterol. 2003;9(3):516-20. [PubMed: 12632509].

19. Kusters JG, Gerrits MM, Van Strijp JA, Vandenbroucke-Grauls CM. Coccoid forms of Helicobacter pylori are the morphologic manifestation of cell death. Infect Immun. 1997;65(9):3672-9. [PubMed: 9284136].

20. Mizoguchi H, Fujioka T, Nasu M. Evidence for viability of coccoid forms of Helicobacter pylori. J Gastroenterol. 1999;34 Suppl 11:32-6. [PubMed: 10616763].

21. Ren Z, Pang G, Musicka M, Dunkley M, Batey R, Beagley K, et al. Coccoid forms of Helicobacter pylori can be viable. Microbios. 1999;97(388):153-63. [PubMed:10413871].

22. Cellini L, Allocati N, Angelucci D, Iezzi T, Di Campli E, Marzio L, et al. Coccoid Helicobacter pylori not culturable in vitro reverts in mice. Microbiol Immunol. 1994;38(11):843-50. [PubMed: 7898382].

23. Saito N, Konishi K, Sato F, Kato M, Takeda H, Sugiyama T, et al. Plural transformation-processes from spiral to coccoid Helicobacter pylori and its viability. J Infect. 2003;46(1):49-55. [PubMed: 12504609].

24. Shahamat M, Mai U, Paszko-Kolva C, Kessel M, Colwell RR. Use of autoradiography to assess viability of Helicobacter pylori in water. Appl Environ Microbiol. 1993;59(4):1231-5. [PubMed: 8489232].

25. Cellini L, Del Vecchio A, Di Candia M, Di Campli E, Favaro M, Donelli G. Detection of free and plankton-associated Helicobacter pylori in seawater. J Appl Microbiol. 2004;97(2):285-92. doi: 10.1111/j.1365 2672.2004.02307.x. [PubMed: 15239694].

26. Costerton JW, Lewandowski Z, DeBeer D, Caldwell D, Korber D, James G. Biofilms, the customized microniche. J Bacteriol. 1994;176(8):213742. [PubMed: 8157581].

27. Linke S, Lenz J, Gemein S, Exner M, Gebel J. Detection of Helicobacter pylori in biofilms by real-time PCR. Int J Hyg Environ Health. 2010;213(3):176-82. doi: 10.1016/j.ijheh.2010.03.006. [PubMed: 20427237].

28. Hatakeyama M. Helicobacter pylori CagA and gastric cancer: a paradigm for hit-and-run carcinogenesis. Cell Host Microbe 2014;15(3):306-16. doi: 10.1016/j.chom.2014.02.008. [PubMed: 24629337].

29. Bakhtiari S, Alvandi A, Pajavand H, Navabi J, Najafi F, Abiri R. Development and Diagnostic Evaluation of Loop-Mediated Isothermal Amplification Using a New Gene Target for Rapid Detection of Helicobacter pylori. Jundishapur J Microbiol. 2016;9(5):ee28831. doi: 10.5812/jjm.28831. [PubMed: 27540449].

30. Pajavand H, Alvandi A, Mohajeri P, Bakhtyari S, Bashiri H, Kalali B, et al. High Frequency of vacA s1m2 Genotypes Among Helicobacter pylori Isolates From Patients With Gastroduodenal Disorders in Kermanshah, Iran. Jundishapur J Microbiol. 2015;8(11):ee25425. doi: 10.5812/jjm.25425. [PubMed: 26862378].

31. Climatology and geography of Kermanshah . Climatology and geography of Kermanshah province 2012. Available from: www. kermanshahmet.ir.

32. Kermanshah water and sewage company . Kermanshah water and sewage company Kermanshah 2012. Available from: http://www. abfaksh.ir/ab/.

33. Stolte M, Wellens E, Bethke B, Ritter M, Eidt H. Helicobacter heilmannii (formerly Gastrospirillum hominis) gastritis: an infection transmitted by animals?. Scand J Gastroenterol. 1994;29(12):1061-4. [PubMed: 7886392].

34. Chen XJ, Yan J, Shen YF. Dominant cagA/vacA genotypes and coinfection frequency of $\mathrm{H}$. pylori in peptic ulcer or chronic gastritis patients in Zhejiang Province and correlations among different genotypes, coinfection and severity of the diseases. Chin Med J (Engl). 2005;118(6):460-7. [PubMed: 15788126].

35. Amiri N, Abiri R, Eyvazi M, Zolfaghari MR, Alvandi A. The frequency of Helicobacter pylori in dental plaque is possibly underestimated. Arch Oral Biol. 2015;60(5):782-8. doi: 10.1016/j.archoralbio.2015.02.006. [PubMed: 25766471].

36. Dunn BE, Cohen H, Blaser MI. Helicobacter pylori. Clin Microbiol Rev. 1997;10(4):720-41. [PubMed: 9336670]. 
37. Farthing MJ. Helicobacter pylori infection: an overview. Br Med Bull. 1998;54(1):1-6. [PubMed: 9604425].

38. Brown LM. Helicobacter pylori: epidemiology and routes of transmission. Epidemiol Rev. 2000;22(2):283-97. [PubMed: 11218379].

39. Piqueres P, Moreno Y, Alonso JL, Ferrus MA. A combination of direct viable count and fluorescent in situ hybridization for estimating Helicobacter pylori cell viability. Res Microbiol. 2006;157(4):345-9. doi: 10.1016/j.resmic.2005.09.003. [PubMed: 16380234].

40. Goodman KJ, Correa P, Tengana Aux HJ, Ramirez H, DeLany JP, Guerrero Pepinosa $\mathrm{O}$, et al. Helicobacter pylori infection in the Colombian Andes: a population-based study of transmission pathways. Am J Epidemiol. 1996;144(3):290-9. [PubMed: 8686698].

41. Hulten K, Han SW, Enroth H, Klein PD, Opekun AR, Gilman RH, et al. Helicobacter pylori in the drinking water in Peru. Gastroenterology. 1996;110(4):1031-5. [PubMed: 8612990].

42. Mazari-Hiriart M, Lopez-Vidal Y, Calva JJ. Helicobacter pylori in water systems for human use in Mexico City. Water Sci Technol. 2001;43(12):93-8. [PubMed: 11464777].

43. Watson CL, Owen RJ, Said B, Lai S, Lee JV, Surman-Lee S, et al. Detection of Helicobacter pylori by PCR but not culture in water and biofilm samples from drinking water distribution systems in England. J Appl Microbiol. 2004;97(4):690-8. doi: 10.1111/j.1365-2672.2004.02360.x. [PubMed: 15357718].

44. Hulten K, Enroth H, Nystrom T, Engstrand L. Presence of Helicobacter species DNA in Swedish water. J Appl Microbiol. 1998;85(2):282-6. [PubMed: 9750301].

45. Horiuchi T, Ohkusa T, Watanabe M, Kobayashi D, Miwa H, Eishi Y. Helicobacter pylori DNA in drinking water in Japan. Microbiol Immunol. 2001;45(7):515-9. [PubMed: 11529557].

46. Hegarty JP, Dowd MT, Baker KH. Occurrence of Helicobacter pylori in surface water in the United States. JAppl Microbiol. 1999;87(5):697-701. [PubMed: 10594710]

47. Khan A, Farooqui A, Kazmi SU. Presence of Helicobacter pylori in drinking water of Karachi, Pakistan. J Infect Dev Ctries. 2012;6(3):2515. [PubMed: 22421606].

48. Boomkens SY, Kusters JG, Hoffmann G, Pot RG, Spee B, Penning LC, et al. Detection of Helicobacter pylori in bile of cats. FEMS Immunol Med Microbiol. 2004;42(3):307-11. doi: 10.1016/j.femsim.2004.06.002. [PubMed: 15477044].

49. Engstrand L. Helicobacter in water and waterborne routes of transmission. Symp Ser Soc Appl Microbiol. 2001(30):80S-4S. [PubMed: 11422563].

50. Fox JG, Batchelder M, Marini R, Yan L, Handt L, Li X, et al. Helicobacter pylori-induced gastritis in the domestic cat. Infect Immun. 1995;63(7):2674-81. [PubMed: 7790084].

51. Neiger R, Simpson KW. Helicobacter infection in dogs and cats: facts and fiction. J Vet Intern Med. 2000;14(2):125-33. [PubMed:10772482]

52. Van den Bulck K, Decostere A, Baele M, Driessen A, Debongnie JC, Burette $A$, et al. Identification of non-Helicobacter pylori spiral organisms in gastric samples from humans, dogs, and cats. J Clin Microbiol. 2005;43(5):2256-60. doi: 10.1128/JCM.43.5.2256-2260.2005. [PubMed: 15872252].

53. Covacci A, Falkow S, Berg DE, Rappuoli R. Did the inheritance of a pathogenicity island modify the virulence of Helicobacter pylori? Trends Microbiol. 1997;5(5):205-8. doi: 10.1016/S0966-842X(97)01035-4.
[PubMed: 9160510].

54. Hansen R, Berry SH, Mukhopadhya I, Thomson JM, Saunders KA, Nicholl CE, et al. The microaerophilic microbiota of de-novo paediatric inflammatory bowel disease: the BISCUIT study. PLoS One. 2013;8(3):ee58825. doi: 10.1371/journal.pone.0058825. [PubMed: 23554935].

55. Powers-Fletcher MV, Couturier MR. Non-Helicobacter pylori Helicobacter Species Associated with Human Disease: a Primer for the Clinical Microbiology Laboratory. Clin Microbiol Newsletter. 2015;37(12):93-101. doi: 10.1016/j.clinmicnews.2015.05.004

56. Yang J, Ji S, Zhang Y, Wang J. Helicobacter hepaticus infection in primary hepatocellular carcinoma tissue. Singapore Med $\mathrm{J}$. 2013;54(8):451-7. [PubMed: 24005452].

57. Yamazaki S, Yamakawa A, Okuda T, Ohtani M, Suto H, Ito Y, et al. Distinct diversity of vacA, cagA, and cagE genes of Helicobacter pylori associated with peptic ulcer in Japan. J Clin Microbiol. 2005;43(8):390616. doi: 10.1128/JCM.43.8.3906-3916.2005. [PubMed: 16081930].

58. Peek RM Jr, Miller GG, Tham KT, Perez-Perez GI, Zhao X, Atherton JC, et al. Heightened inflammatory response and cytokine expression in vivo to cagA+ Helicobacter pylori strains. Lab Invest. 1995;73(6):76070. [PubMed: 8558837].

59. Parsonnet J, Friedman GD, Orentreich N, Vogelman H. Risk for gastric cancer in people with CagA positive or CagA negative Helicobacter pylori infection. Gut. 1997;40(3):297-301. [PubMed: 9135515].

60. Blaser MJ, Perez-Perez GI, Kleanthous H, Cover TL, Peek RM, Chyou PH, et al. Infection with Helicobacter pylori strains possessing cagA is associated with an increased risk of developing adenocarcinoma of the stomach. Cancer Res. 1995;55(10):2111-5. [PubMed: 7743510].

61. Crabtree JE, Taylor JD, Wyatt JI, Heatley RV, Shallcross TM, Tompkins DS, et al. Mucosal IgA recognition of Helicobacter pylori $120 \mathrm{kDa}$ protein, peptic ulceration, and gastric pathology. Lancet. 1991;338(8763):332-5. [PubMed: 1677696].

62. Hong TC, Mai QL, Cuong DV, Parida M, Minekawa H, Notomi T, et al. Development and evaluation of a novel loop-mediated isothermal amplification method for rapid detection of severe acute respiratory syndrome coronavirus. J Clin Microbiol. 2004;42(5):1956-61. [PubMed: 15131154].

63. Parida M, Horioke K, Ishida H, Dash PK, Saxena P, Jana AM, et al. Rapid detection and differentiation of dengue virus serotypes by a realtime reverse transcription-loop-mediated isothermal amplification assay.J Clin Microbiol. 2005;43(6):2895-903. doi:10.1128/JCM.43.6.28952903.2005. [PubMed: 15956414].

64. Aryan E, Makvandi M, Farajzadeh A, Huygen K, Alvandi AH, Gouya $\mathrm{MM}$, et al. Clinical value of IS6110-based loop-mediated isothermal amplification for detection of Mycobacterium tuberculosis complex in respiratory specimens. J Infect. 2013;66(6):487-93. doi: 10.1016/j.jinf.2013.02.005. [PubMed: 23466595].

65. Aryan E, Makvandi M, Farajzadeh A, Huygen K, Bifani P, Mousavi SL, et al. A novel and more sensitive loop-mediated isothermal amplification assay targeting IS6110 for detection of Mycobacterium tuberculosis complex. Microbiol Res. 2010;165(3):211-20. doi: 10.1016/j.micres.2009.05.001. [PubMed: 19515543].

66. Notomi T, Okayama H, Masubuchi H, Yonekawa T, Watanabe K, Amino $\mathrm{N}$, et al. Loop-mediated isothermal amplification of DNA. Nucleic Acids Res. 2000;28(12):E63. [PubMed: 10871386]. 